\title{
Literature Study: Cultivating Civic Skills through Student Organizations in Higher Education
}

\author{
Teddy Tamara ${ }^{1}$, Sapriya ${ }^{2}$ \\ \{teddytamara@upi.edu ${ }^{1}$,ksapriya@yahoo.com² $\}$ \\ Universitas Pendidikan Indonesia, Indonesia ${ }^{1,2}$
}

\begin{abstract}
This study conducted to gather sufficient information regarding the cultivation of civic skills through student organizations. The method used in this study is a literature study that collects several previous studies to find out how to instill civic skills through student organizations. The results of the study showed that student organizations in instilling civic skills, namely through socialization as a medium for disseminating information and selecting organizational activity programs that can arouse students' mindsets to think critically, responsibly, and scientifically. Common obstacles faced in implanting civic skills are external and internal constraints such as licensing, funding, secretariat, coordination, lifestyle, lack of student interest, and different student backgrounds. However, student organizations have their own ways of overcoming the obstacles faced in implanting civic skills.
\end{abstract}

Keywords: Civic skills, student, student organizations.

\section{Introduction}

Higher education institutions are required to play a role in forming the next generation of the world, not only as committed citizens and skilled workers, but also as representatives of organizations, societies and nations [1],[2]. Student activities in higher education besides learning activities in classrooms, there are also activities in student organizations. Student organizations are places where students gather to form groups to achieve common goals. Student organizations are a place to develop their functions and roles as students, such as developing intellectual personalities that will later be useful for entering society. Involvement of students in organizations is as one of opportunities for them to develop skills. It can help students in promoting their professional interests and developing professional skills [3].

Student organizations are a vital part of the extracurricular program at most colleges and universities. In the increasingly litigious society of today, how-ever, student organizations are no more immune from legal concerns and the threat of litigation than the institution as a whole is. The courts have recog-nized that colleges and universities have certain obligations toward students who desire to associate with one another in an organized fashion for any number of purposes. The courts have also recognized that institutions have certain responsibilities relating to the operation of recognized student groups [4]

The existence of student organizations almost coincides with the existence of educational institutions. Student organizations in secondary schools have become widely recognized among students through various co-curricular or extracurricular activities [5]. In 2015, more than 25 percent of students reported being involved in student organizations during their first year at college [6]. Student organizations provide opportunities for students to build social networks on campuses and also provide important experiences for students while studying in college [7]. Universities involvement in providing a valuable context for students to express several questions that need to be studied and analyzed [8]. 
Several studies have shown that there is an increase in student leadership knowledge and skills while in college [9],[10] and other research — such as the Multi-Institutional Study of Leadership —is began to demonstrate high-impact experiences in building student leadership capacity (including socio-cultural interactions with peers, mentoring relationships, community service, and membership in off-campus organizations) [11]. However, little is known about how and why they learned and developed these skills. While this is a good starting point for understanding how student leadership develops, more research is needed [12]. Foubert and Grainger have reported that students who were more involved in student organizations had greater skill development scores than students who were not involved [13].

Much literature has revealed that student organizations provide opportunities for individuals to acquire or develop good communication skills, enable them to learn from other people of different ethnicities, and provide support to less fortunate people among them [14]. Participation and involvement of members in organizations supported by the university seem to provide different opportunities for students to become acquainted with campus life and also promote intellectual development [15].

Participating students perceive contributions in student organizations as an essential element of socialization, and their academic persistence provides participants with the resources to excel in an academic environment. [16]. It is recommended that students complete their studies while participating in the organization. The more students participate in the organization, the more likely they are to increase important skills that will be useful in dealing with the real world [3].

The importance of students in joining organizations because organizations provide benefits for students themselves. Student organizations require students to interact directly with other individuals, students are trained to have an attitude of initiative, assertiveness, openness, and empathy. Through these student organization activities, students are encouraged to become active individuals in interacting with other individuals. Furthermore, student participation in various student organization activities will also develop their skills in resolving conflicts, both those occurring within the organization and interpersonal conflicts. Through various experiences in student organizations, students can get greater opportunities to hone their sensitivity and social and communication skills and can learn ways to develop social networks, both on and off campus, ways to adapt to the social environment and ways to maintain warm interpersonal relationships with others. In addition, through student activities, students are also accustomed to living together, working together, and developing close relationships with other individuals.

Student organizations have an important role to play in training and equipping skills to go into society. In a student organization, it must be able to accommodate students to aspire, train students to solve problems quickly and accurately, have responsibilities, and develop civic skills. Students are also trained to have critical thinking about an event and to be responsive to events that will occur around them. Organizational life provides resources for democratic discussion, training in sound decision-making, and encourages collective action within and between student organizations [17]. Debate clubs and literary communities facilitate the development of speech and political skills required in legislative, judicial and civic activities [18].

Citizenship skills are important skills in developing the civic engagement capacity of citizens. Research shows that individuals who have citizenship skills to participate in civic activities have a higher rate than individuals without citizenship skills to participate [19]. Citizenship skills have been defined as the "communication and organizational skills" needed to engage effectively in politics such as discussing politics and communicating with political figures. Individuals who develop civic skills are more likely to become involved politically, be able to engage effectively, and be able to use their time and money more efficiently. In addition, citizen involvement the state plays an important role in helping the student community to change the unfair structures of their community by teaching them the skills needed to work with others towards more equitable outcomes. This makes the community the perfect place to reach out to a group of individuals who are not normally mobilized in our political system. However, research is very limited on citizen involvement in the student community on campus [20]. 
In addition, education should encourage skills such as critical thinking or decision-making or collaborating which are also referred to as civic skills, but the foundations of civic skills require more basic explanations in the literature [21]. Center for Information and Research on civic Learning and Engagement (2003) in a comprehensive report highlights that civic skills do not exist in a vacuum; they are part of a larger set of ideas about what it is believed necessary for citizens to engage in public life. The idea that, in addition to knowledge, some type of 'skill' is required for citizens to participate effectively in public life makes intuitive sense. Thus, civic skills can be categorized as personal communication skills, knowledge of the political system, and the ability to think critically about the life of citizens and politics [22].

\section{Method}

The method used in this study is a literature study that collects several previous studies to determine how to cultivate civic skills through student organizations. Literature study is an activity to study data sourced from books, magazines, journals, and scientific papers as well as other reading materials that can be used as references to increase knowledge and find a solution to problems or phenomena through an analysis.

\section{Discussion}

Higher education institutions should focus on core competencies [23]. Core competencies include (1) effective communication; (2) critical thinking skills; (3) character building; (4) preparing citizenship; (5) diversity of life; (6) preparing a global society; (7) obtain broader interests; (8) career and vocational development.

According to researchers, involvement in student organizations has contributed to skills development [7],[8],[14]. In many colleges and universities, students are not required to be involved in student organizations. However, students are well served and gain leadership experience and other skills through various activities outside of formal learning [3].

Students can improve the quality of their education by developing knowledge, skills and competencies through involvement in several extracurricular activities on campus such as student organizations. Student involvement in student organizations has long been studied as a major contributor to student development. However, there is still much to be learned about student organizations and their impact on student development. Previous research has shown that student involvement in activities outside the classroom has been shown to be an important factor in student development [24]. Employers are looking for students who have the knowledge, skills and competencies to work in their company [23].

Higher education institutions must continue to study the impact of student involvement in student organizations because these organizations provide social opportunities for students to be involved in campus life in universities. Student engagement enhances degree attainment and achievement. Continued participation and networking can stimulate students to apply their college experience to success [7]. Student involvement promotes degree attainment. Continual participation and networking can stimulate students to negotiate their college experiences successfully [25].

Interaction between students is useful and student organizations provide opportunities for students to interact with each other, form close relationships, and provide a better understanding of the relationships they develop [26]. Student organizations that serve as gateways can enable students to grow more competent, interdependent, purposeful, and congruent. Student communities should (1) encourage regular interaction between students and support ongoing relationships; (2) provide opportunities for students to collaborate; (3) make each member feel important; (4) involving people from various backgrounds; (5) serving each reference point for students by maintaining certain limits and norms through certain rules so that members have a standard by which to evaluate their behavior [27]. 
In the perspective of Citizenship Education, student organizations must be a means of support for students to develop soft skills that are important to be used to be able to directly engage in society. These soft skills are known as civic skills. Civic skills have two domains, namely intellectual abilities and participation skills such as interacting, observing, analysing, and evaluating [28]. There are two key components of civic skills: active listening and a respect for diversity [29]. Civic skills also include intellectual and participation skills, such as analyzing, evaluating, interacting, or observing [28].

Based on a holistic perspective, there are two types of student organizations based on their activity environment, namely extra-universal student organizations (extra organizations) and intra-university student organizations (intra organizations). In general, students can be grouped into two types, namely students who are active and students who are apathetic to student organizations. Students who are active in student organizations are students who fully participate by becoming members in student organizations. Meanwhile, students who are apathetic towards student organizations are students who think that student organizations only interfere with academic activities and it is better not to be active in the organization. This is indeed a problem that has occurred for a very long time because it cannot be separated from the assumption that student organizations are only the ones that carry out demonstrations and riots. Apart from that, the negative opinion that often arises is that campus activists tend to take a long time in their studies and result in drop-out.

There are many benefits that come from being organized. Each individual in the organization has different characters and traits. Therefore, by organizing we will learn how to communicate with other people, be it with the younger, the peers and the older. Organizing will also gain experience in how to talk and deal with important people, for example communicating with the dean and the rector. Likewise, when holding activities that go directly to the community, they will be trained on how to communicate with the community.

The existence of student organizations in higher education is important in terms of developing youth potential, as stated in Law of the Republic of Indonesia Number 40 of 2009 concerning Youth Article 3 that is:

Youth development aims at the realization of youths who believe in and fear God Almighty, have noble character, are healthy, intelligent, creative, innovative, independent, democratic, responsible, competitive, and have a leadership, entrepreneurial, pioneering spirit., and nationality based on Pancasila and the 1945 Constitution of the Republic of Indonesia within the framework of the Unitary State of the Republic of Indonesia.

One of the soft skills that students get from student organizations is civic skills, including intellectual skills and citizen participation skills which aim to form good citizens. It is clear that student organizations have long played an integral role in shaping campus life, developing student leaders, and influencing local and national politics.

The form of socialization used by student organizations in developing civic skills is to use the media to facilitate the activities they carry out [30]. The media can be organized in a way: first, materials that can be read (readable, legible), such as newspapers, magazines and others that are mass publications. Second, broadcasts such as audible radio and television and movies that can be seen and heard (audio-visual); and third, association institutions in society, such as mosques and churches that deliver sermons, and possibly through formal or informal institutions [30]. Then the student organization functions to train students to be ready to go into society. In student organizations, students are required to have the courage to express their opinions, have the courage to make decisions quickly, have the power of responsibility, and can cultivate the values of civic skills. This can be seen from its ability to criticize public policies. Students as young intellectuals must be critical of any public policies issued by the government, both on a national and local scale. Thus the knowledge and skills of citizenship are the basis for the formation of the character of citizenship. This makes it clear that in organizing students must have a character ${ }^{30}$.

There are problems during the implementation of civic skills development activities, namely internal and external problems. For example, regarding funding, licensing, lifestyle, communication and coordination, lack of student interest, different student backgrounds, facilities, and regarding the secretariat. Another obstacle for example felt by the Student Regiment organization is related to uniforms 
that have not been facilitated by the campus. All of these become significant obstacles or obstacles for a student organization. The factor that hinders activities carried out by student organizations is the obstacles that are closely related to the development of civic skills. The efforts made by student organizations in overcoming these inhibiting factors by preserving the organizational culture. For example, by creating a strong cadre system, both formally and informally, creating an agenda and work program that can attract students' interest in organizing, the urgency of organizing, the benefits of organizing, and accommodating student aspirations so that they can be directed according to their interests. This is done in a gentle, nonpatronizing manner.

Further research was carried out by Yayuk Hidayah and Sunarso (2017) who examined "Mastery of Civic Skills for Student Executive Board Activists (Studies at Yogyakarta State University)" [31]. The results of these studies indicate that: (1) The role of the Yogyakarta State University Student Executive Board in improving activist civic skills is as a Partner of Yogyakarta State University, that is, being able to work together between the rector and the Yogyakarta State University Student Executive Board by being a "good" partner, providing constructive criticism and suggestions to The chancellor for the welfare of Yogyakarta State University students, as a facilitator covering aspirations, namely acting as a reservoir and channel for the aspirations of Yogyakarta State University students with the chancellor, is responsible for carrying out the Tri Darma of Higher Education, one of which is community service.

Afterwards, As a means of developing talent, namely a community organizer in the form of a group of people who work not only at the level of work program implementation, but also on issues of change that occur around them. Yogyakarta State University Student Executive Board activists can channel their interests and talents according to their fields, learn to socialize and interact in a healthy manner, increase their creativity and leadership spirit. The function of regeneration in the Student Executive Board of Yogyakarta State University is to create dynamic conditions in order to produce independent cadres in thinking, behaving, and acting, as well as being facilitators towards optimizing the role of students as intellectual and social beings. (2) Yogyakarta State University Student Executive Board program that can improve activists' civic skills includes the work program of the cabinet secretary ministry including ministerial secretarial forums, matriculating work programs, creating and monitoring picket schedules, making and managing announcement boards, monitoring boards of administrators. Barriers that arise in improving the civic skills of activists of the Yogyakarta State University Student Executive Board are internal and external obstacles. Internal obstacles include limited human resources, many work programs and minimal finance. External barriers include technical barriers and changes in social and political conditions. The efforts made by the Student Executive Board of Yogyakarta State University are systematic recruitment, prioritizing the effectiveness of work programs, establishing partnerships, activating notice boards, regular field meetings and reading the socio-political situation.

Further research on the cultivation of civic skills through organizations was also carried out by Ardiana Elsa and Eka Vidya Putra (2019) who researched "External Campus Organizations as Containers for Student Softskill Development (Case Study: Padang State University Students Participating in Campus External Organizations))" [32]. With the research subject consisting of five external organizations, namely the Islamic Student Association (HMI), the Indonesian Muslim Student Action Union (KAMMI), the Indonesian Islamic Student Association (PMII), the Indonesian National Student Movement (GMNI), and the Muhammadiyah Student Association (IMM). The results showed that external organizations can develop student soft skills such as communication skills, critical thinking, and leadership skills. The results of this study can be seen as below:

1. Student organizations collectively have the resources to develop the soft skills of their members.

2. The resources that exist in campus external organizations will develop student soft skills such as leadership, communication skills and critical thinking. 
3. Five external organizations (HMI, KAMMI, PMII, IMM, GMNI) have resources to develop soft skills for their members.

From the three studies above, it can be concluded that the existence of student organizations in higher education is important in the context of student self-development, especially in instilling civic skills. Student organizations include, of course, diverse human resources (because the organization is a collection of people), natural and environmental resources, goals to be achieved, and the means or instruments used in achieving the intended objectives [30].

\section{Conclusion}

Based on this study, it can be concluded that student organization is a vehicle or means for students who serve as a channel of aspiration and creativity in the process of self-development, especially in the process of civic skills development. In addition, student organizations have a very large role in the development of student civic skills because in organizations, students are fostered and equipped to be ready to jump into the community. Student organizations instill civic skills through socialization as a medium of dissemination of information and select organizational activity programs that can awaken the student mindset to think critically, responsibly, and scientifically. A common obstacle faced in instilling civic skills is external and internal constraints such as licensing, funding, secretariat, co-ordination, lifestyle, lack of student interest, as well as different student backgrounds. However, student organizations have their own way to overcome the obstacles faced in instilling civic skills.

\section{References}

[1] Astin, A. W., \& Astin, H. S. (2000). Leadership reconsidered. Battle Creek, MI: W.K. Kellogg Foundation.

[2] Benson, L., Harkavy, I., \& Puckett, J. (2007). Dewey's dream: Universities and democracies in an age of education reform. Philadelphia, PA: Temple University Press.

[3] Patterson, B. (2012). Influences of student organizational leadership experiences in college students' leadership behaviors. E Journal of Organizational Learning \& Leadership, 10(1), 1-12.

[4] Cuyjet, M.J., Gilbert, N.S., \& Conboy, P.M. (1983). Student Organizations: Some Legal Implications. San Francisco: Josscy-Bass.

[5] Eccles, J. S. (2005). The present and future of research on activity settings as developmental contexts. Mahwah, NJ: Lawrence Erlbaum.

[6] Rios-Aguilar, C., Eagan, K., \& Stolzenberg, E. B. (2015). Findings from the 2015 administration of the your first college year (YFCY) survey. Los Angeles, CA: Higher Education Research Institute.

[7] Kuk, L., \& Banning, J. (2010). Student organizations and institutional. College Student Journal, 44, 2.

[8] Huang, Y. R., \& Chang, S. M. (2004). Academic and cocurricular involvement: Their relationship and the best combinations for student growth. Journal of College Student Development, 45(4), 391 406.

[9] Mayhew, M. J., Rockenbach, A. H., Bowman, N. A., Seifert, T. A., Wolniak, G. C., Pascarella, E. T., \& Terenzini, P. T. (2016). How college affects students: 21 st century evidence that higher education works (Vol. 3). San Francisco, CA: Jossey-Bass.

[10] Pascarella, E. T., \& Terenzini, P. T. (2005). How college affects students: A third decade of research. San Francisco, CA: Jossey Bass.

[11] Dugan, J. P., Kodama, C., Correia, B., \& Associates. (2013). Multi-Institutional Study of Leadership insight report: Leadership program delivery. College Park, MD: National Clearinghouse for Leadership Programs. 
[12] Allen, S. J., \& Hartman, N. S. (2009). Sources of learning in student leadership development programming. Journal of Leadership Studies, 3, 6-16. https://doi.org/10.1002/jls.20119.

[13] Foubert, J. D., \& Grainger, L. U. (2006). Effects of involvement in clubs and organizations on the psychosocial development of first-year and senior college students. Journal of Student Affairs Research and Practice, 43(1), 166-182.

[14] Harper, S. R., \& Quaye, S. J. (2007). Student organizations as venues for Black identity expression and development among African American male student leaders. Journal of College Student Development, 48(2), 127-144.

[15] Montelongo, R. (2002). Student participation in college student organizations: A review of literature. Journal of the Indiana University Student Personnel Association, 50-63.

[16] Flowers, L. A. (2004). Examining the effects of student involvement on African American college student development. Journal of College Student Development, 45(6), 633-654.

[17] Robiadek, K.M., Strachan, J.C., \& Bennion, E.A. (2019). Assessing Democratic Engagement through Student Organizations. Journal of Student Affairs Research and Practice. 56(5), 595-607.

[18] Rosch, D. M. \& Collins, J. D. (2017). New directions for student leadership. Published online in Wiley Online Library (wileyonlinelibrary.com).

[19] Verba, S., Schlozman, K. L., \& Brady, H. E. (1995). Voice and equality, civic voluntarism in American politics. New York, NY: Harper \& Row.

[20] Newell, M.A. (2016). The Community Colleges' Role in Developing Students' Civic Outcomes: Results of a National Pilot. Community College Review. Vol. 44(4) 315-336.

[21] Ata, A. (2019). Fostering Students' Civic Skills: Education for Sustainable Democracy. Volume 16, Issue 1.

[22] Comber, M. K. (2003). Civics curriculum and civic skills: Recent evidence. College Park, MD: The Center for Information and Research on Civic Learning and Engagement (CIRCLE). Retrieved from http://www.civicyouth. org/PopUps/FactSheets/FS_Civics_Curriculum_Skills.pdf.

[23] Bok, D. (2006). Our underachieving colleges: A candid look at how much students learn and why they should be learning more. Princeton, NJ: Princeton University Press.

[24]Cox, E. R., Krueger, K. P., \& Murphy, J. E. (1998). Pharmacy student involvement in student organizations. Journal of Pharmacy Teaching, 6(3), 9

[25] Simmons, L. D. (2013). Factors of Persistence for African American Men in a Student Support Organization. The Journal of Negro Education, 82(1), 62-74.

[26] Bryant, A. N. (2007). The effects of involvement in campus religious communities on college student adjustment and development. Journal of College and Character, 8(3).

[27] Chickering, A. W., \& Reisser, L. (1993). Education and Identity. San Francisco, CA: Jossey-Bass.

[28] Kokom Komalasari. 2016. The effect of contextual learning in civic education on students' civic skills. International Journal for Educational Studies, 4(2) 179-190.

[29] Smith, R. (2012). Set charge about change: The effects of a long-term youth civic engagement program. Journal of Community Engagement \& Scholarship, 5(2), 48-60.

[30] Kosasi. 2016. Peranan Organisasi Kemahasiswaan Dalam Pengembangan Civic Skills Mahasiswa. JPIS, Jurnal Pendidikan Ilmu Sosial, Vol. 25, No. 2. https://doi.org/10.17509/jpis.v25i2.6196.

[31] Yayuk Hidayat dan Sunarso. 2017. Penguasaan Civic Skills Aktivis Badan Eksekutif Mahasiswa (Studi di Universitas Negeri Yogyakarta). Harmoni Sosial: Jurnal Pendidikan IPS Volume 4, No 2, September 2017 (153-164). http://journal.uny.ac.id/index.php/hsjpi.

[32] Elsa Ardiana dan Eka Vidya Puta. 2019. Organisasi Eksternal Kampus Sebagai Wadah Pengembangan Softskill Mahasiswa (Studi Kasus : Mahasiswa Universitas Negeri Padang Yang Mengikuti Organisasi Eksternal Kampus). Jurnal Perspektif: Jurnal Kajian Sosiologi dan Pendidikan Vol. 2 No. 3. http://dx.doi.org/10.24036/perspektif.v2i3.100 